A grant of $\$ 7,500$ will be provided to successful applicants to underwrite their travel and living expenses incurred during up to two weeks of training at one or more host institutions. The funds are also intended to provide for roundtrip travel and four nights' accommodations at the annual meeting of the Association scheduled for May 9-13, 2009 in Boston, Massachusetts. The fellowship must be completed prior to March 31, 2009.

Applicants must have the approval of their home and prospective host institutions. Candidates must complete an AATS application and include a one-page outline of what they hope to accomplish during their training. Additionally, award recipients must agree to submit a summary report to the membership of the association within thirty days after the completion of their training.

The candidate must be a North American resident in their final year of an ACGMF approved cardiothoracic surgical training program.

Applications are available online at www.aats.org and must be completed no later than July 1, 2008. The selected candidates will be notified by September 30, 2008.

\section{Third Edward D. Churchill Research Scholarship 2009-2011}

$\mathrm{T}$ he American Association for Thoracic Surgery announces the Third Edward D. Churchill Research Scholarship to provide an opportunity for research, training, and experience for North American surgeons committed to pursuing an academic career in cardiothoracic surgery. The scholarship will be funded by the Association and administered by the Graham Education and Research Foundation.
The research program must be undertaken within the first three years after completion of an approved cardiothoracic residency. Applications for the scholarship may be submitted during the candidate's final year of cardiothoracic residency or during his or her first two years in an academic position. The duration of the scholarship is to be two years.

The yearly stipend shall be $\$ 80,000$ paid to the host institution for salary support, research supplies, travel, and other legitimate academic expenses of the scholar. The application consists of three components:

1. The candidate must submit a proposal for the research to be undertaken and a statement of career plans and how the research activity will relate to the candidate's academic career.

2. The director of the laboratory in the institution at which the research will be performed shall submit an endorsement of the proposal and indicate the facilities and degree of support available for the candidate's research.

3. The chairman of the candidate's department shall submit his or her endorsement of the proposal and indicate the willingness of the institution to provide an academic appointment for the candidate upon completion of the scholarship.

The application and its components must be submitted online at www.aats.org by July 1, 2008. Announcement of the award will be made by the president of The American Association for Thoracic Surgery December 15, 2008. The scholarship will begin July 1, 2009. Following completion of the two-year program, the scholar shall submit a written report of his/her research activities to the membership of the Association.

\section{The Western Thoracic Surgical Association}

\section{Announcement of 2008 Annual Meeting}

$\mathrm{T}$ The Thirty-fourth Annual Meeting of the Western Thoracic Surgical Association will be held June 25-28, 2008 at the Sheraton Keauhou Bay Resort \& Spa, Kona, Hawaii. The scientific sessions are open to all duly qualified physicians. Participation in other Association activities for members, invited guests, and program participants requires payment of a social registration fee.

\section{Requests for Meeting Information}

Meeting preregistration and hotel registration forms are available from:

Western Thoracic Surgical Association

900 Cummings Center

Suite 221-U

Beverly, MA 01915

978-927-8330; fax: 978-524-8890

wtsa@westernthoracic.org

\section{Material for the Program}

Scientific papers will be considered from members and nonmembers. Member sponsorship is not necessary.

For the 2008 Annual Meeting, abstract submission opened in midNovember, 2007. All abstracts were submitted electronically via the WTSA Web site. The abstract deadline was early January, 2008.

\section{Application for Membership}

Applications for membership in the Association must be received by the Membership Committee Chairman no later than March 1, 2009 to be considered for the following annual meeting. Applicants must be sponsored by three members of the Association who are not members of the Membership Committee. Application forms will be issued only to sponsoring members.

Address correspondence to:

Chairman, Membership Committee

The Western Thoracic Surgical Association

900 Cummings Center

Suite 221-U

Beverly, MA 01915

978-927-8330; fax: 978-524-8890

wtsa@prri.com 